AL-TA'LIM JOURNAL 22 (2), 2015, (180-193)

(Print ISSN 1410-7546 Online ISSN 2355-7893)

Available online at http://journal.tarbiyahiainib.ac.id/index.php/attalim

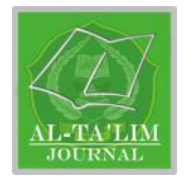

\title{
The Using of Media in Learning Fiqh to the Islamic Education Department of Education and Teacher Faculty of IAIN Imam Bonjol Padang
}

\author{
Ahmad Sabri ${ }^{* 1}$ \\ Department of Islamic Education IAIN Imam Bonjol Padang \\ Gusmaneli \\ Department of Islamic Education IAIN Imam Bonjol Padang \\ ${ }^{1}$ Email : ahmadsabri81@yahoo.co.id \\ DOI: http://dx.doi.org/10.15548/jt.v22i2.145
}

Received: 11th April 2015; Revised: 6th June 2015; Accepted: 20th July 2015

\begin{abstract}
The using of media in learning is one of important aspects to be applied in learning process, the delivery of learning material is easy to understand, in addition to the provide more concrete learning, specially in the achievement of learning objectives. The aims of this study is to reveal the use of Media in Learning Fiqh in the Department of Islamic Education, Education and Teaching Faculty of IAIN Imam Bonjol Padang. This study used a qualitative descriptive method, the informants of this study is consisted of lecturers who teach jurisprudence at the Department of Islamic education, the other jurisprudence lecturers, students and subsequently increased in accordance with the purposes of the data obtained. Data collected by using observation, interviews, and documentation, to the validity of the data obtained, it is conducted the triangulation during the research process. The research results revealed that the Use of Media in Learning Fiqh of the Department of Islamic Education in Teaching Faculty of IAIN Imam Bonjol Padang by lecturers already in used, such as using a doll to organize the corpse, shroud, perfume, coffin corpse and occasional lecturer use media electronics such as laptop. This was due to the limited facilities and infrastructure that provide in Department of Islamic Education, Tarbiyah Faculty of IAIN Imam Bonjol Padang, and the instability of electricity power, thus, the most frequently media that is used by lecturer is a whiteboard using the discussion method.
\end{abstract}

Keywords: Media, Learning of jurisprudence, Department PAI (islamic education)

\section{INTRODUCTION}

Education is performed through the learning process; essentially, learning is an interaction process between teachers and students, with the result that the student behavior turn to be better. This education process is a deliberate conscious effort which is designed to achieve the goal. Education aims to improve the quality of human resource. Learning process in university is one way to reach the goal of the enhancement of human resource.
In increasing the quality of education, lecturer or educator is an essential aspect that must be increased and developed continuously, so that the learning process goes properly and perfect. To gain professional lecturer can be carried out through pre-service education program and in-service education program.

This faculty resource potency needs to be developed in order to enable the lecturers to perform his duty professionally. Besides that, the development of fast-paced knowledge and technology helps lecturers continuously expand their quality and adjust to development of knowledge and society mobility. In Indonesian 
constitution no 142005 concerning teacher and lecturer written that:

" Teacher is professional educator with teaching and educating as his main duty, guiding, directing, training, judging and evaluating the learners on early childhood formal education, basic education and middle education.

Hence, be a lecturer is not easy, it needs professional skill in achieving the goals, with the sense of static jobs, but dynamic jobs everchanging, in accordance with the development of science and technology, Lecturers are required to be sensitive to the dynamics of developments in society, it include the progress of ever-changing needs, social development, culture, politics, including the development of technology. In achieving the learning objectives, Lecturers are required to use the media of learning and teaching methods which are appropriate and varied. A lecturer should know what should be done in order to create a situation of creative teaching and learning so that students easily understand the material presented. And the purpose that is desired by lecturers and effort to create an atmosphere of exciting learning and fun for all students, one of the factors that affect teaching and learning atmosphere is the use of educational media in the learning process. In the process of learning jurisprudence, lecturers are required to use the media maximally, so the learning process that arises should be more concrete. Learning is as a process within a system that can not be separated from other components that interact with each other. One of components in the process is a source of learning; learning source is a power that can be utilized for the purpose of teaching and learning, either directly or indirectly.

In Higher Education to achieve the goal of learning is influenced by the use of media, in learning process, it takes an important role, in the learning activity, obscurity of delivered material can be helped by presenting the media as intermediaries, the complexity of materials that will be presented to the student can also be simplified with the help of the media. Media represented by what is less capable of lecturers say through words or certain phrases. Even the material abstraction can be concreted by media presence.

It means the more concrete learning media. The more students easily and quickly digest the material presented. Based on the quote above can be understood that, the use of the media is one of the important components the learning process in Higher Education. The use of media is believed as an important aspect in the goals of learning.Therefore, the preparation of instructional media as one of the responsibilities of lecturer. Correspondingly, the spread of advances in communications and technology and the high dynamics in the world of education is also expanding demands and opportunities for media use more advanced and varied in the learning process. In addition, the media also serves to overcome boredom and fatigue resulting from lecturer's unclear explanation to be understood. The use of media enables to support the learning objectives, so that the learning objectives achieved perfectly.

One of teacher roles is as a mediator; they should have sufficient knowledge and understanding of the use of the media, because the media is a communication tool for more effective teaching and learning process. The use of instructional media in teaching and learning can generate motivation and stimulation of learning activities and even bring psychological effects on students, based on the observation that the researcher did during teaching at the Faculty of Teaching where lecturers use the media in learning, students who are taught will be more instantly understood and figure out their learning and they also comprise higher motivation than the lecturers who are use the lecture method.

\section{Instructional Media}

In general, Instructional Media is learning and teaching tool. Everything that can be used to stimulate the mind, feeling, attention and ability or skill of learners can encourage the process of learning; this limitation is quite extensive and includes in-depth understanding 
of the source, the environment, human and methods that used for the purpose of learning / training, the use of creative media will allow students to increase their learning and improve their performance in accordance with desired goals

According to Briggs (1977) instructional media is the physical facilities to deliver content / learning materials such as: books, films, videos, etc. Then, according to the National Education Association (1969) revealed that the learning media is a means of communication in the form hearing, including hardware technology. Therefore, the learning process is a process of communication and takes place in a system, then learning media occupy an important part as one component of learning systems, without media, communication will not occur and the learning process as a communication process also can not take place optimally, because the learning media is an integral component of the learning system.

From the opinion above, it can be concluded that the learning media is anything that can deliver the message, can stimulate thoughts, feelings, and the willingness of learners and reach the goal of learning process to the students.

According to Edgar Dale, in education, the use of instructional media often uses the Cone Experience principle, requiring media such as textbooks, learning materials which are created by teachers and "audio-visual".

\section{Gambar: Kerucut Pengalaman Edgar Dale}

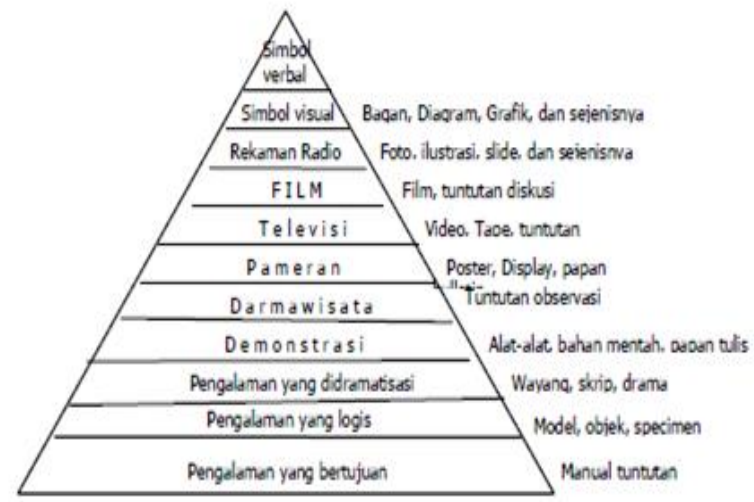

Sumber : Arif (1994 : hal. 79)

\section{The Type of Instructional Media}

There are several types of media, including

1. Visual Media: graphs, diagrams, charts, charts, posters, cartoons, comics

2. Audio Media : Audio, tape recorders, language laboratories

3. Still Projected Media: slide; over head projector (OHP), in focus

4. Motion Projected Media: movie, television, video (VCD, DVD, VTR), computers.

In essence, learning is not media itself that determines the learning outcomes, the success of using instructional media in the learning process to improve learning's' outcomes depend on (1) message content, (2) how to explain the message, and (3) the characteristics of message recipient, Thus, in selecting and using media, it is need to be noted these three factors. If these three factors are able to be delivered in instructional media, definitely, it will provide maximum results.

\section{The purpose of using instructional media}

There are several objectives using instructional media, such as:

a. Facilitate Teaching-Learning Process

b. Improving the efficiency of learning

c. Maintain the relevance of the learning objectives

\section{d. Helping student concentration}

In choosing instructional media, it is need to be well-suited to the needs, circumstances and each condition. It depend to the teacher how he can develop it appropriately, it is viewed of content, message description and characteristics of students to determine the instructional media

\section{Media Choosing Criteria}


Selecting the media should not be done arbitrarily, but based on certain criteria.

The unsuitable of choosing, both the choice of media and the selection of topics, will carry bad impact for the long term, Many questions need to be answered before determining the choice of certain media. Generally, the criteria that should be considered in the preparing of instructional media described as follows:

\section{a. Purpose}

What learning goals (standards and basic competencies) to be achieved?, is it in the cognitive, affective, psychomotor, or a combination?, What kind of sensory stimulation emphasized: vision, hearing, or a combination? If the visual, does it need the movement or visual silent only? The answer to that question will lead us to certain media types, whether realia media, audio, visual silent, visual motion, audio visual motion and so on.

\section{b. Target Learners}

Who are the target students who will use the media? How are their characteristics, how much, how is their social background, how is motivation and interest in learning? And on, If we ignore these criteria, then the media we choose does not give significant function. Why? Because in the end, this is the goal that would take advantage of the media we choice. Therefore, the media must exactly correspond to their condition.

\section{c. Characteristics of the media concerned}

How is the characteristic of the media? What are the advantages and disadvantages is it corresponding with the objectives to be achieved? We will not be able to choose the media well if we are not familiar with the characteristics of each media. Because choosing is basically an activity of comparing each other, which one is better and more suitable than other? Therefore, before deciding on a particular media type, be well understand how the media Characteristics.

\section{d. Time}

The meaning of time is how long it takes to hold or make the media we choose, as well as how much time is available / that we have, is that enough?

\section{e. Cost}

The use of media is basically intended to improve the efficiency and effectiveness of learning. It is useless, if the result actually waste. Therefore, the cost factor should be the criteria that considered, how much the cost that need to be spent, buy or use the media, Is there any other media alternatives are cheaper but still can reach the goal of learning? Expensive media is not necessarily more effective to achieve the goal of learning than simple and inexpensive media.

\section{f. Availability}

Simplicity in obtaining media must be also considered, Are there media around us, in school or on the market?

\section{g. Context Usage}

Usage Context means in condition and the intention strategy of how the media will be used. For example: is to learn individual, small group, large group or mass?

\section{h. Technical quality}

These criteria mainly to choose / purchase ready-made media that already exist, such as audio programs, videos, graphics or other print media. Technical quality of the media, visual clear, attractive, and fit; clear and pleasant voice

\section{Principles Use of Media}

Decent media does not necessarily guarantee the success of student learning if we can not use it well. Therefore, the media that we have chosen should be utilized in the best possible according to the principles of media utilizationthere are some general principles that we need to consider in the use of instructional media, those are: Each type of media has its 
advantages and weaknesses

There is no type of media that is suitable for all of the learning process and can achieve all the goals of learning. We can say that, no drug that works for all types of diseases.

a. The use of multiple types of media is varied indeed necessary. However, note!, the use of various media at once in a learning activity will confuse the student and will not clarify the lesson, therefore, use the media as necessary.

b. The use of the media should be able to treat students actively. use a simple media that enable all students to be active instead of sophisticated media which lead students to be passive, Before the media are used, it must be planned perfectly in lesson plans

c. Decide which part of the material that will serve with the media. Plan how to use the strategies and techniques, avoid using distraction media, if students realize that the media used only for distraction, then this impression will always appear every time the teacher uses the media

d. Indiscriminate use of media, random origin, or "rather than useless", will raise negative consequences or worse, the media must be prepared enough before use, lack of preparation will work on the effectiveness and efficiency of learning process and also interfere the process of learning, give strong attention before using the instructional media.

e. General and Special benefit of Media in Learning, the benefits of media is to facilitate the interaction between teachers and students, so that learning activities will be more effective and efficient, But. there are several detail benefits of media.

\section{The function of Instructional Media}

Some of the functions of instructional media are:

a. Instructional media can serve as the focus of students' attention.
Especially if it is an interesting learning media, students will always focus their attention to new things shown or taken by the teacher in the classroom. So be always sure to use instructional media

\section{b. Arouse Students Emotions}

Student emotions towards something (learning materials) can be easily stirred by using instructional media. For example, they can quickly sympathize to the people who have disabilities by just watching short videos on a disability who should be able to perform a variety of daily activities independently. With similar instructional media we can teach students to love the environment and concerned with the preservation of the natural around.

c. To help students understand the learning material. If the teacher intends to use instructional media and managed effectively, the teacher must choose instructional media in accordance with the purpose of learning

d. Help students to organize information. A variety of instructional media such as power point which is designed earnestly provides graphs or charts, or diagrams, help students easily organize learning materials. Teachers enable to deliver it by attaching special symbols that reinforce students retention

\section{e. Arouse students' learning motivation}

Teachers who use instructional media in teaching and learning activities able to raise an interesting class room the atmosphere. One of the reasons is because instructional media has an important function as motivation enhancement. Students are motivated to learn when teachers provide variety of appropriate instructional media

\section{f. Construct more concrete learning}

Many abstract concepts that must be learned by students in the classroom. The easiest way to present something abstract is to help them through the learning media. Abstract 
learning is difficult to be learned, reverse it with more concrete learning.

g. Overcoming the limitedness of space, time, and power senses

Many events, concept, or object that must be learned by the students but it is hard to present it directly. For example, if the teacher wants to take the students to the times of the 2nd world war, the teacher can present it in a media of learning. Many documenting videos Second World War is available on the internet, by presenting it in the class, the limitations of space and time can be overcome, if the teacher wants to convey how the shape of an amoeba that is taking food, it only by instructional media can be achieved.

h. Enabling the learning

It is believed, the use of instructional media will enable learning in the classroom. Moreover, the selected learning media able to facilitate many students and allow them to interact

i. Reduce the possibility of teacher-centered learning

Instructional media used by teachers when teaching can prevent teachers to always carried on this possibility, especially teachers who carefully choose the media that allows the orientation of student-centered learning

\section{j. Enabling student response}

Many students are not excited to respond the learning given, because the monotonous of teachers, learning that utilize a variety of learning media and appropriate learning objectives enable to raise the solution, students will give a positive response during the learning process.

\section{Learning process}

Learning comes from word "study" which is gained affixes, prefix pe and suffix an. For giving evident explanation, the authors state the definition of learning according to the experts as follows:

a. According to koneksionisme pioneered by Thorndike argues:

"Learning is an attempt to establish the relationship between stimulus and response".

b. Behaviorism believes

"Learning is an attempt to adapt to the conditions or situations around us. In adapting into the situation, it includes the receiving of dexterity of new understanding and attitudes"

c. Psycho Reflexology states that he study is:

"Learning is seen as an attempt to form new reflexes. This sect believes that learning is a series of acts that form the artificial reflex. $"$

d. The Psychology Association argues that

"Learning is an active process; active means is not an activity that looks like a body movement, but also mental activities, such as the process of thinking, remembering, and so on".

All these opinions show that learning is a process of the interaction between educators and learners in adapting to the circumstances, it able to stimulate mental activity, such as in the process of thinking, remembering and understanding.

Mustaqim and Abdul Wahib said "Teaching can be interpreted extensively and narrowly. As narrowly, learning is the process of delivering knowledge to students. While in the broadest sense, the teaching covers all activities that create comfortable learning situations. "

In a narrow sense, teaching is simply convey the understanding to the students, this sense assumed that student more likely to be passive, because student only received the information or knowledge, in wide terms, teaching is the activity to organize or set the 
environment as well as possible and connect with students, so that the learning process as an attempt to create comfortable conditions for learning activities to students and teachers. That condition were created in a way to help the child optimally, both physical and spiritual, both physically and mentally

S. Nasution formulates the teaching as follows:

a. Teaching is inheriting knowledge among students

b. Teaching is conveying the culture to children

c. Teaching is an activity to organize and connect with a child to create the learning process. "

Teaching is assumed to be successful based on the recognition that learning essentially is a meaningful process, not only happen mechanically.

Having described the sense of learning and teaching, the author describes the definition of learning according to the expert as follows:

1. According to the National law of Education System (UUSPN) Article 1 NO.20 2003.

"Learning as a process of learners' interaction and learning resources in an environment"

2. According to E. Mulyasa

"Learning is a process of interaction between the learners and the environment, so the interaction changes towards the better."

3. According to Irpan Abdul Gafur and Muhammad Jamil

"Learning is an attempt to drive the student behavior after the learning process toward the better".

4. According Syaiful Sagala

"Learning is a process of two-way communication; the teaching is done by the teacher as an educator, while the study carried out by students or pupils."

From the definition above, it is understood that learning as a process of individual interaction with the environment, which is managed to drive the interest of student better behavior, and enable to gain the better improvement.

\section{Jurisprudence/fiqh}

The word 'Fiqh' comes from the Arabic language

means: knowing something ( الفقه - يققهـ فقها) and understand.

$$
\text { الفقه لغة الفعهم فقهت كلامك اى فهمت }
$$

Fiqh according to the language: understand, then I know your words, it means I understand.

Meanwhile, according to the term, there are various Fiqh concepts which are expressed by the scholars in different editors, including:

1. According to Abu Zahra, Fiqh is

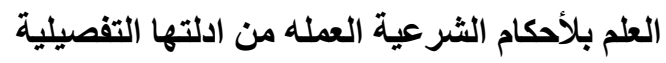

Science that discuss the laws of Personality 'that is charity and (fetched) from the detailed arguments

Based on the definition above, Abu Zahra divided the Object of Fiqh into two parts:

a) The science of Shari'a laws that are charity.

b) Science that discusses the detailed arguments for each issue

2. Wahab al-Zuhaili argues that, Fiqh is :

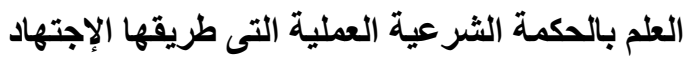

The Science that associated with the laws of charity and it is obtained or generated from the detailed argument 
3. Definitively Ibn Subki said in his book Jam'u al-Jawanni ', jurisprudence means the " fiqh is the science of the shari'a laws which is charity that is excavated and recovered from the valid postulates".

4. Abdul Hamid Hakim in his book "Sulam", Fiqh means:

$$
\text { العلم بالحكام الثرعية العملية التى طريقها الاجتهاد }
$$

Knowing the Islamic laws in any manners or ways with self-diligence.

Base on curriculum of Islamic school, Fiqh is the field of Islamic study which is designed to prepare students to recognize, appreciate and practice the Islamic law, which later became the basis of life view through the activities of counseling, instruction, training and experience practice.

Based on the explanation above, the authors concluded that the jurisprudence is a science in the Islamic Shari'ah which specifically discuss the issue of Islamic rules which is relating to the person, either permitted or forbidden and compulsory or permissible and human relationships with each other, based on postulates of the verses of Al Qur'an an Sunnah of the Prophet.

\section{Basic Law of learning Fiqh}

The low of learning fiqh is divided into two categories:

1) the science of fiqh are required to be learned by all Muslims as an obligation, such as studying of prayer, fasting and others

2) the science of fiqh is required to be learned by some Muslim people, fasakh, ruju ( devorcement) ', the requirements to be a qadi, or judge and others

Meaning: Why there is no one among them decided to seek and deepen their knowledge of religion and to give a warning to his people when they have returned to him, so that they can maintain themselves. (QS. At-Tawbah: 122)

Based on the verse above, it can be understood that Allah command to some Muslims to seek Islamic knowledge in order to delivered to his brothers, because it is supposed to all Muslims to study Islam in depth. the Prophet Muhammad also said:

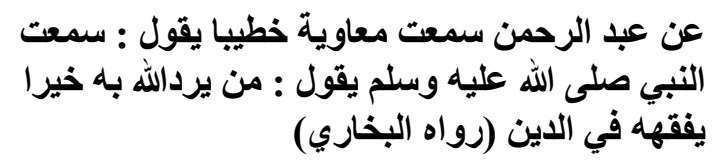

Meaning : From Abd al-Rahman, I heard Muawiya in the sermon he said, I heard the Prophet SAW said: Whoever is willed by Allah will be given His goodness and virtue, undoubtedly, Allah gives him breadth of understanding in religion" (Bukhari and Muslim).

Based on Hadith above, learning fiqh is an obligation for muslim, Some are required to be learned by all Muslims (obligatory 'ain). Such as studying the ordinance of prayer, purification and other. And there were required to be learned by some people in the group of Muslims (fard kifayah). Such as studying the problem of fasakh, ruju' (divorcement), the requirement to be a judges.

a. The purpose and usefulness of Fiqh

The basis purpose of studying Fiqh:

1. To seek the general understanding of the Islamic religion.

2. To learn Islamic laws which is related to human life

3. The Muslims must study in-dept, meaning that deepen their knowledge of religious laws, both in the field of faith, and morals as well as in worship and Trading.

To carry out the teaching and learning process of Fiqh, it need to be considered, what 
is contained or outlined in studying the Fiqh, The purpose of study Fiqh in Islamic Junior High School (MTsN) is to prepare the learners to be able to:

a) To be able to understand the main points of Islamic law detail and comprehensively, either proposition naqli( the law from Al-Quran and Hadits) and aqli (brain or faith). Those Knowledge and understanding are expected to be the way of live in personal and social.

b) Perform and practice the stipulations of Islamic law correctly. The experience is expected to arouse obedience to practice Islamic law, discipline and high responsibility in personal and social life

Based on the explanation above, it can be concluded that, the purpose of studying Fiqh is an Islamic Shari'ah (islamic law), in every word and deed of learners and to encourage awareness of worship to Allah and to establish shari'ah (islamic law) outright. The function of Study fiqh is very important for humans, because it leads people to goodness and devoted to Allah. With the the Fiqh, people will learn which is obligatory and prohibitions that should be shunned. Therefore, the field of study Figh that is given to such learners should be mastered, followed, analyzed and applied by students in the concrete situation that receives in everyday life.

\section{b. Scope of Fiqh}

Musthafa Ahmad Zarqa divided the explanation of fiqh into seven parts:

1. The provisions which is relating to the worship, such as prayer, fasting and hajj.

2. The provisions of the law relating to family life, such as marriage, divorce, relative, this is referred to Fiqh ahwal alSyakhshyiyah

3. Legal provisions relating to social relationships between Muslims in the context of economic relations and rights, such as the sale and purchase, lease and lien. The field is then called Fiqh muamalah.

4. The provisions of the law governing the relationship problems of citizens with the government in relation to rights and obligations. This discussion is called fiqh al-Siyasah

5. Legal provisions relating to the actions against the perpetrators of crimes or criminal acts, such as the Qisas (giving equitable punishment), Diyat(fine), and hudud(certain punishment). This field is called the Fiqh Jinayah

6. The law that governing the Islamic State relations with other countries

7. The provisions governing the association between a Muslim with each other in the social life

According to Dahlan Adul Aziz, the scope of the study is:

"Every action of Muslim that has value and determined its law. The value maybe mandatory, sunnah, permissible, forbidden, besides that, the field of Fiqh discussion only relates to the problem amaliah (practice). "

Fiqh discussion always associated with detailed charity from the Qur'an and Sunnah, through in-depth analysis study. According to Wahab Al-Zuhaili, he said that the object of Fiqh only confined to relate to the laws of amaliyah, such as; Prayer, fasting, buying and selling, debts, etc.

Based on the explanation above, it can be understood that the subject of Fiqh is the deed of mukallaf according to what has been specified of its legal provisions. Therefore in the science of Fiqh which is discussed about the laws of syara' concerning the relationship with Allah, called "worship" in its various aspects, human relationships with each other in family relationships, relationships with others in the field of material and so on. 


\section{Research methods}

The method used in this research is descriptive qualitative research method, because researchers intent to disclose the use of media in teaching jurisprudence (fiqh) at the Department of Islamic Education Faculty of IAIN Imam Bonjol Padang.

This study emphasizes the use of media in teaching jurisprudence at the Department of Islamic Education Faculty of Teaching IAIN Imam Bonjol Padang. And to understand the phenomenon as a whole, it must also understand the context and conduct a holistic analysis and it needs to be described, the data collection techniques in this study using observation, interview and documentation study. Whereas instruments are used researchers themselves.

The data analysis was conducted by examining the fit between each data. So it can be extracted the truth. And key informants in this study, the professor who teaches in the department of teaching and Islamic education and students.

\section{THE STEPS OF RESEARCH}

This study basically follows the steps these steps: (1) establish a research focus, (2) formulate research questions, (3) observation, (4) conduct interviews with relevant parties, (5) the triangulation with related parties (6) write research reports.

\section{RESEARCH RESULT}

\section{A. The use of Media in Learning Fiqh of the Department of Islamic Education in the Faculty of Teaching IAIN Imam Bonjol Padang}

1. The use of Media by the lecturer in the course of jurisprudence (fiqh)

The information that gained from the interview on 8 October 2013 with Fiqh
Lecturer of Islamic Education Department of teacher and teaching Faculty IAIN Imam Bonjol as follows:

"We are as the lecturer in the Department of Islamic Education, using media in teaching jurisprudence to students, but, the media we use is very simple, and it is generally used by every lecturer, such as, blackboard. White board, puppets, shroud, water, prayer mats, and sometimes our own as a media by using demonstration method in teaching it. And for multimedia, we rarely used, because of its availability on our campus, especially in the department of Islamic education, it is very limited, and another problem is the instability of electricity.

It means that the lectures used the media in teaching (fiqh) jurisprudence, but the media is still very simple and use the method of demonstration and lecture.

2. Lecturers' purpose of Using Media in Teaching Fiqh.

In an interview with Fiqh Lecturers on 8 October 2013, they said: Our goal using the media in the teaching jurisprudence is to help the student easily understood and apply it into their daily life

The Meaning of these circumstances is the purpose of media use by lecturers in teaching jurisprudence in order to achieve the learning outcomes for students, which students can practice it into their life.

3. Function of Media Use in the learning of jurisprudence (fiqh)

The interview with Fiqh Lecturer when met at the office on 9 October2013,saidthat: The use of media in learning is not only enables students easily understand but also enables students to practice in their self or to other people around them.

The meaning contained in these circumstances is in teaching the discussion that related to the implementation of corpse, 
the lecturers use media directly and students also enable to practice directly.

4. The Consideration of Lecturer in choosing the media to be used in the learning of Fiqh.

The interviews with Fiqh Lecturer when met at his office on October 10, 2013, he said:

In choosing the media that will be used, first we adjust to the goal, then adjust with what materials will be given, Then we use the media. Because we know that the material of learning in the jurisprudence a lot, and broad in scope, then we adjust its media what is fits. Because we know that not all media are suitable for all materials. For example, sometimes we use only a blackboard, with the burden on students for discussion, we sometimes assign students to collect newspaper and magazine articles if the material that will be given in the form of buying and selling and mudarabah (profit shares)

The meaning that contained in these circumstances is to use the media to teach Lecturer observes the purpose and the material to be taught.

5. Media types which are often used in

Teaching and Learning Fiqh

Researcher interviews with Fiqh lecturer when the encounter in the Lecturer room on October 10, 2013, he said:

Media that we often use in teaching jurisprudence is the board using the lecture method, honestly, we actually intent to use a sophisticated media in teaching such as multimedia for example the in focus for teaching, but the available media in the majors and especially in Teaching Faculty is very limited, in addition, it also the electricity power does not work properly, the electricity usually off, it hampered the using of media other than white board.
The significance of this situation is Lecturers and students eager to use more sophisticated media multimedia such as infocus, but the faculty infrastructure is very limited.

\section{B. The Availability of Media in Learning of Fiqh At the Department of Islamic Education.}

1. Types of Media which are available at the Department of Islamic education

Researchers Interviews with Fiqh Lecturer Fiqh on October 25, 2013 they said:

In using media for learning fiqh, we used it, the media we use is brought by the students themselves, as the practice material of corpse, it is because the media that will be used is not all available in the majors, except coffin corpse,And it is also the media that available in the faculty is an infokus, but somewhat difficult to borrow because it is often used for other activities in the faculty, it's limited. So we rarely use the infocus media, and also because of the unstability of electricity as we have also said before.

The significance of this situation is only one infocus that is available in the majors, so that the lecturer's rather difficult to borrow, as availability is limited.

2. The Effect of media that used to Fiqh Learning Outcomes

Researchers Interviews with Fiqh Lecturer on October 24, 2013 ,they said:

Honestly, actually by the using of media, the student easily to master the materials we delivered, especially if if those who intent to practice it themselves. It will be a long forgetfulness. And we hope the knowledge that we share to these students is not only useful for them, but more than that, they were able to practice and also teach for those around him 
The significance of this situation is to study by concrete in order to improve student results.

\section{The supporting and inhibiting Factors of the media use in learning Fiqh.}

1. The supporting Factors in the using of media

The results of interviews with Fiqh Lecturers on 22 October 2013 , the argue:

The students Motivation and curiosity to the material presented in the learning of jurisprudence adapted with the times that are present, so that it is requires for lecturers to use media in learning, In addition to concrete media, the student directly adapted into environment.

To strengthen the information, the researcher interview Other Fiqh Lecturer on October 23, 2013 said:

The development of science and technology, so it requires the Lectures to be able to adapt to these developments. Moreover, the material of jurisprudence is very closely associated with the development of the era, such as the development of online trade, now it appears that buying and selling online. This is a challenge that lecturers should be ready to adapt it.

The significance of this situation is to increase student motivation and curiosity to understand the learning material of jurisprudence.

\section{The Inhibiting Factor in Learning Fiqh}

Researcher's interviews with Lecturers, on October 24, 2013 in lecturer's room, they said:

We as the lecturers of jurisprudence would like to use the media in teaching jurisprudence, but this is due to limited media available on the Teaching faculty, particularly in the Department of Islamic Education, Besides the use of electronic media and electricity power are also constrained, in addition to the above situation, the most urgent is the level of student understanding, because we know that, students background is not only from Islamic school but also from many high schools education. for the student who come from Islamic school, they are more easily understand the material presented, but for students whose educational background of high school or such as, This enables lecturer to work extra hard in explaining. That's why the media are very helpful in explaining the material presented.

\section{E. The Effort in Using of Media in Learning Fiqh}

1. The Effort in Using of Media in Learning Fiqh

The interviews with Fiqh Lecturer when encountered in the lecturers room on August 14, 2007 , they said:

We are lecturers who teach jurisprudence, the media such as laptop and infocus are not available on campus, and we use our own media to teach in campus, but it also requires the students to look for existing media surrounding for example, by collecting newspaper clippings, and then the student initiative to buy media, such materials related to the implementation of the corpse, in the faculty or in the Islamic Education Department was not available such as media, then the student buy it, or if there is a privately owned by student, they took it into learning.

The significance of this situation is due to the limited media, lecturers and students tried to provide their on media to the teaching and learning process.

\section{CONCLUSION}

1. The lecturers use media in teaching jurisprudence at the Department of Islamic Education Teaching Faculty of IAIN Imam Bonjol Padang 
2. The Lecturers use media in teaching jurisprudence in order to enable student easily understand the material presented, and students able to apply in their lives.

3. The type of media that is often used is a white board and sometimes the form of electronic media, because of the limitations of media available in the Department of Islamic Education Teaching Faculty of IAIN Imam Bonjol Padang, and instability of electricity.

4. The efforts made in the use of media by the lecturers of jurisprudence to the students are giving the tasks, and lecturers bring their own electronic media such as laptop.

\section{REFERENCE}

Asnawir et al. (2001). Media pengajaran. Padang : IAIN press.

Aziz, Dahlan Abdul. (1996). Enciklopedi Hukum Islam. Jakarta: Ichtiar Baru Van Hoeve.

Bogdan, R And Biklen, K.S. (1982). Qualitative, Research In Education : an Introduction to Teory and Methodes Boston : Allyn and Bacon Inc.

Bogdan, R And Taylor, S.S. (1982). Kualitatif Dasar-dasar Penelitian (Translated: A Khozin Afandi). Surabaya : Usaha Nasional.

Depag R.I, Kurikulum Madrasah Tsanawiyah Standar Kompetensi, (Jakarta :tt)

Depag R.I.(2004). Kurikulum Madrasah Tsanawiyah Standar Kompetensi. Jakarta : Direktorat Jendral Kelembagaan Agama Islam.

Departemen Agama RI. (1995). Al-Qur'an dan Terjemahnya. Semarang : PT. Karya Toho Putra.
Faisal. (1990). Penelitian Kualitatif, Dasardasar dan Aplikasi. Malang Yayasan Asuh Asah Asuh.

Gay L.R. (1987). Education Research Competencief for Analysis and Application. Florida : Merril Publishing Company.

Himpunan Redaksi Grafika. (2003). UUSPN.NO.20 th 2003. Jakarta: Sinar Grafika.

IGafur rpan Abd. dan Muhammad Jamil. (2003). Reformasi Rencana Pembelajaran Pendidikan Agama Islam. Jakarta: Nur Insani.

Koto, Alauddin. (2004). Ilmu Fiqh dan Ushul Fiqh. Jakarta : PT. Grafindo Persada.

Mansur, Ibnu. (1992). Lisan al-Arab, Juz.1. Beirut : Dar Ihya'.

Moleong, Lexy. (1997). Metode Penelitian Kualitatif, Bandung, PT Remaja Rosda Karya.

Mulyasa E. (2004). Kurikulum Berbasis Kompetensi, Konsep Karakteristik dan Implementasinya. Bandung: PT. Remaja Rosda Karya.

Sadiman, Arief, et al. (1996). Media Pendidikan. Jakarta: CV Raja Wali.

Sagala Syaiful. (2005). Konsep dan Makna Pembelajaran,. Bandung: Alvabeta.

Sanjaya Wina. (2008) Strategi Pembelajaran, Jakarta : Kencana.

Spradley.J.P. (1980). Participant Abservation. Nevd:jow Rehart and Wiston.

Sudjana N and Ibrahim. (1989). Penelitian dan Penilaiaii Pendidikan, Bandung : Penerbit Sinar Baru Bandung.

Suhertian Piet A. (2009). Supervisi Pendidikan, Jakarta : Publisher.

Syafi'i, Karim. (1997). Fiqih dan Ushul Fiqih. 
Bandung : Pustaka Setia.

Syaiful, Djamarah Bahri et al. (1997). Strategi Belajar Mengajar, Jakarta: Rineka Cipta.

Syarifuddin Amir. (2003). Garis-Garis Besar Fiqih. Jakarta :Kencana

Undang - undang RI No. 14 Tahun 2005 tentang Guru dan Dosen, 2006, Bandung : Citra Umbara.

Usman B. (1999). Metodologi Pengajaran
Agama Islam. Padang : IAIN Press.

William D. (1989). Penelitian Naturalistik (translated: Lexy moleong) Jakarta: Pasca Sarjana IKIP Jakarta.

Zarqah , Musthafah Ahmad. (1968). alMadkhal al-Fiqh al-'Aam, juz I. Damascus : al-Adid,.

Zuahaili Wahab al-. (1984). al-Fiqh al-Islam wa Adillahu, juz I. Kairo : al-Fikr. h.15-16 